\title{
Antinociceptive properties of the essential oil of Ocimum gratissimum L. (Labiatae) in mice
}

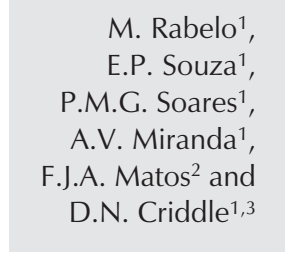

\section{Correspondence}

D.N. Criddle

MRC Secretory Control Research

Group

The Physiological Laboratory

University of Liverpool

Crown Street

Liverpool L69 3BX

UK

E-mail: criddle@liv.ac.uk

Research supported by FUNCAP and CNPq.

Received May 10, 2002

Accepted December 20, 2002

\author{
${ }^{1}$ Laboratório de Farmacologia dos Canais lônicos, \\ Departamento de Ciências Fisiológicas, Universidade Estadual do Ceará, \\ Fortaleza, CE, Brasil \\ ${ }^{2}$ Laboratório de Produtos Naturais, Departamento de Química Analítica e \\ Físico-Química, Universidade Federal do Ceará, Fortaleza, CE, Brasil \\ ${ }^{3}$ MRC Secretory Control Research Group, The Physiological Laboratory, \\ University of Liverpool, Liverpool, UK
}

\section{Abstract}

We have investigated the antinociceptive effects of the essential oil of Ocimum gratissimum L. (Labiatae) (EOOG) in two classical models of pain in male Swiss mice (25-35 g), the writhing test and the formalin test. At doses of 30, 100 and $300 \mathrm{mg} / \mathrm{kg}$ (po), EOOG produced a dosedependent inhibition (from $58.3 \pm 4.4$ to $40.7 \pm 6.3,36.4 \pm 3.6$ and 24.6 \pm 3.6 , respectively; $\mathrm{N}=8$ - $10, \mathrm{P}<0.05$ ) of acetic acid-induced writhing, causing up to a $\sim 60 \%$ inhibition at the highest dose used, comparable to that obtained with indomethacin $(10 \mathrm{mg} / \mathrm{kg}, p o)$. At the same doses, EOOG predominantly inhibited the late (inflammatory) phase of the formalin-induced pain response (from $59.3 \pm 8.3$ to $40.4 \pm 4.8,23.2 \pm$ 2.8 and $25.3 \pm 5.5$, respectively; $\mathrm{N}=6, \mathrm{P}<0.05$ ), with a maximal reduction of $\sim 60 \%$ of the control, although a significant reduction of the initial (neurogenic) phase was also observed at $300 \mathrm{mg} / \mathrm{kg}$ (from $62.5 \pm 6.07$ to $37 \pm 5.9 ; \mathrm{P}<0.05$ ). On the basis of these data, we conclude that EOOG possesses interesting antinociceptive properties in the writhing and formalin tests. Due to the relatively low toxicity of EOOG, further detailed examination is strongly indicated for a better characterization of its pharmacological properties and its potential therapeutic value.

In the Northeast of Brazil the plant Ocimum gratissimum L. (Labiatae), commonly known as "Alfavaca-cravo", is widely used for medicinal as well as culinary purposes. One of the many uses of the plant is for digestive problems and we have recently shown that the essential oil of $O$. gratissimum (EOOG) has relaxant effects on the isolated guinea-pig ileum (1). However, many other common uses of $O$. gratissimum exist. For example, this plant is used as an antiseptic (2) and for the treatment of cough, fever and
Key words - Ocimum gratissimum L. - Labiatae - Essential oil - Antinociception conjunctivitis (3). Generally the flowers and leaves of the plant, which are a rich source of essential oils, are utilized to prepare infusions or teas for the treatment of common ailments (2). Despite a multiplicity of applications in popular folk medicine, there has been surprisingly little pharmacological investigation of the effects of this plant. Interestingly, however, a preliminary report has indicated that an aqueous extract of the Nigerian variety of the plant has nociceptive properties (4). 
Plants are known to be a rich source of naturally occurring antinociceptive substances (5), and in the present study we decided to evaluate the effects of EOOG in two classical pharmacological tests for nociception: the acetic acid-induced writhing test (6) and the formalin test $(7,8)$.

EOOG was obtained from the Horto de Plantas Medicinais of the Departamento de Química Orgânica e Inorgânica, Universidade Federal do Ceará, Fortaleza, CE, Brazil. The plant is registered in the Herbário Prisco Bezerra of the Universidade Federal do Ceará (EAC 14968).

The essential oil was isolated from the leaves of the plant by steam distillation (2). The composition of EOOG, determined by gas chromatography and mass spectrometry, was: $52.14 \%$ eugenol, 29.17\% 1,8-cineole, $5.56 \%$ ß-selinene, $3.35 \%$ trans-caryophyllene, $2.73 \%$ ocimene, $1.58 \% \alpha$-selinene, $1.51 \%$ ß-pinene, and 3.96\% not identified.

In the writhing test, male Swiss mice, 25$35 \mathrm{~g}$, were kept in a temperature-controlled environment $\left(23 \pm 2^{\circ} \mathrm{C}\right)$ with a 12-h lightdark cycle. Food and water were freely available. The abdominal constriction resulting from intraperitoneal injection of acetic acid $(0.8 \%)$, consisting of a contraction of the abdominal muscle together with a stretching of hind limbs, was recorded according to standard procedures (6). Animals were pretreated (po) with EOOG $(10-300 \mathrm{mg} / \mathrm{kg})$ or indomethacin $(10 \mathrm{mg} / \mathrm{kg}) 60 \mathrm{~min}$ prior to acetic acid injection. Control animals received only a similar volume of the solvent (0.1\% Tween 80$)$ used to dissolve EOOG. All experiments were carried out at $20-22^{\circ} \mathrm{C}$. After administration of acetic acid, pairs of mice were placed in separate cages and the number of abdominal constrictions was cumulatively counted over a period of $20 \mathrm{~min}$. Antinociceptive activity was expressed as the reduction of the number of abdominal constrictions observed in test mice pretreated with EOOG compared to control animals pretreated with Tween. In separate experi- ments, indomethacin $(10 \mathrm{mg} / \mathrm{kg}, p o)$ was employed as a positive control for comparison.

Male Swiss mice, 25-35 g, were used in the formalin test according to a procedure described previously $(7,8)$. Animals were pretreated with EOOG (10-300 mg/kg, po) $60 \mathrm{~min}$ prior to the injection of $1.0 \%$ aqueous formalin $(20 \mu \mathrm{l})$ administered by the intraplantar route into the right hindpaw. The amount of time that the animal spent licking the injected paw during the first 5 min (initial phase, neurogenic) and 15-30 min after formalin injection (late phase, inflammatory) was measured. The test was carried out at ambient temperature $\left(20-22^{\circ} \mathrm{C}\right)$ with special care taken to avoid environmental disturbances that might influence the animal's response. Control animals received only the vehicle used to dilute EOOG $(0.9 \%$ $\mathrm{NaCl})$.

Data are reported as mean $\pm \mathrm{SEM}$, with $\mathrm{N}$ indicating the number of animals used. The results were analyzed statistically by the Student $t$-test, with the level of significance set at $\mathrm{P}<0.05$.

Oral administration of EOOG (30-300 $\mathrm{mg} / \mathrm{kg}$ ) induced a dose-dependent inhibition of the number of writhes elicited by acetic acid, with a reduction of approximately $60 \%$ of the control response at the highest dose employed $(\mathrm{N}=10$, Table 1$)$. The dose of 10 $\mathrm{mg} / \mathrm{kg}$ also reduced the mean response, but not significantly $(\mathrm{N}=10)$. In separate experiments, indomethacin $(10 \mathrm{mg} / \mathrm{kg})$ inhibited the acetic acid-induced response by approximately $54 \%$ of the control $(\mathrm{N}=10$; Table 1).

In the formalin test (Table 2), EOOG (30$300 \mathrm{mg} / \mathrm{kg}$ ) elicited a dose-dependent inhibition of licking time during the second phase, with a maximal reduction of approximately $60 \%$ of the control response $(\mathrm{N}=6)$. In addition, a significant reduction of licking time was observed during the first phase at the highest dose of $300 \mathrm{mg} / \mathrm{kg}$ (Table 2).

The present results show for the first time 
that the EOOG has a significant antinociceptive activity in traditional pharmacological models. It has been previously shown that an aqueous extract of the plant also produces this effect (4) and the present data suggest that $O$. gratissimum L. possesses several inherent antinociceptive principles. EOOG had inhibitory effects in both the acetic acidinduced writhing test and formalin test at oral doses of $30-300 \mathrm{mg} / \mathrm{kg}$. This route of administration was chosen for the present study because of the preparation of the plant as infusions and teas in popular medicine, and we suggest that the effects observed in the present study justify the therapeutic uses of the plant.

The magnitude of the inhibitory action of EOOG in the acetic acid-induced writhing test was comparable to that obtained with the standard drug, indomethacin, indicating the importance of our current findings. This test is a standard test for pain that is sensitive to opiates as well as non-opiate analgesics (9). The associated nociceptive response is believed to involve the release of endogenous substances that stimulate nociceptive endings, such as bradykinin and prostanoids, amongst others (10). This test, although highly sensitive to weak analgesics, is also affected by a variety of other pharmacological substances including muscle relaxants and neuroleptics (11), and as such limits definitive conclusions about the mechanism of action of EOOG. It is possible, for example, that a sedative action might also produce a positive result in this test, although this seems unlikely since the locomotor activity of the animals did not appear to be impaired by EOOG within the experimental protocols.

In contrast, the formalin test measures the response to a long-lasting nociceptive stimulus, and may thus bear a closer resemblance to clinical pain (8). The formalin test is divided into two phases: neurogenic (first phase) and inflammatory (second phase) pain. The first phase is attributed to direct activa- tion of peripheral nociceptors and sensory afferent fibers by formalin, while the second phase may reflect a combination of low ongoing activity in primary afferents and increased sensitivity of spinal cord neurons $(12,13)$. Our data show that EOOG exerts inhibitory effects predominantly during the late phase of the formalin response, although the highest dose of EOOG $(300 \mathrm{mg} / \mathrm{kg})$ also produced a significant inhibition of the first phase, and may thus reflect multiple sites of action.

It was beyond the scope of the present study to investigate which component(s) was (were) responsible for the antinociceptive effects of EOOG; however, several appear to be likely candidates. For example, eugenol, the major compound found in our chemical analysis of EOOG, has been shown to have analgesic effects $(14,15)$, possibly via inhibition of nerve conduction through $\mathrm{A}$

Table 1. Effects of the essential oil of Ocimum gratissimum (EOOG) (po) on acetic acidinduced writhing in mice.

\begin{tabular}{lccr}
\hline Group/dose (mg/kg) & Writhes (No.) & Inhibition (\%) & N \\
\hline Control & $58.3 \pm 4.4$ & - & 10 \\
EOOG (10) & $44.7 \pm 6.0$ & 23.3 & 10 \\
EOOG (30) & $40.7 \pm 6.3^{*}$ & 30.0 & 8 \\
EOOG (100) & $36.4 \pm 3.6^{*}$ & 37.6 & 9 \\
EOOG (300) & $24.6 \pm 3.6^{*}$ & 57.8 & 10 \\
Indomethacin (10) & $26.5 \pm 2.6^{*}$ & 54.5 & 10
\end{tabular}

Data are reported as means \pm SEM. $N$ indicates the number of animals per group. ${ }^{*} \mathrm{P}<0.05$ vs control (Student $t$-test).

Table 2. Effects of the essential oil of Ocimum gratissimum (EOOG) (po) on the formalin test in mice.

\begin{tabular}{llllccc}
\hline $\begin{array}{l}\text { Group/dose } \\
\text { (mg/kg) }\end{array}$ & $\begin{array}{c}\text { Licking time } \\
\text { first phase (s) }\end{array}$ & $\begin{array}{c}\text { Licking time } \\
\text { second phase (s) }\end{array}$ & $\begin{array}{c}\text { Inhibition first } \\
\text { phase (\%) }\end{array}$ & $\begin{array}{c}\text { Inhibition second } \\
\text { phase (\%) }\end{array}$ & N \\
\hline Control & $62.5 \pm 6.07$ & $59.3 \pm 8.3$ & - & - & 6 \\
EOOG (10) & $53.66 \pm 14.5$ & $44.3 \pm 9.2$ & 14.1 & 25.3 & 6 \\
EOOG (30) & $61.25 \pm 9.0$ & $40.4 \pm 4.8^{*}$ & 2.0 & 31.9 & 6 \\
EOOG (100) & $57.5 \pm 9.2$ & $23.2 \pm 2.8^{*}$ & 8.0 & 60.9 & 6 \\
EOOG (300) & $37.0 \pm 5.9^{*}$ & $25.3 \pm 5.5^{*}$ & 40.8 & 57.3 & 6 \\
\hline
\end{tabular}

Data are reported as means \pm SEM. $N$ indicates the number of animals per group. ${ }^{*} \mathrm{P}<0.05$ vs control (Student $t$-test). 
and C fibers (16), and/or inhibition of prostaglandin biosynthesis $(17,18)$, although a stimulatory effect on capsaicin-sensitive afferent sensory neurons has also been reported (19). In addition 1,8-cineole, another major compound present in EOOG, possesses both anti-inflammatory and antinociceptive properties (20). Thus, a combination of pharmacological effects probably underlies the observations of the present study.

EOOG $(30-300 \mathrm{mg} / \mathrm{kg})$ has antinociceptive properties in the classical pharmacological tests. Since EOOG is remarkably nontoxic, with an $\mathrm{LD}_{50}$ value $>2.4 \mathrm{~g} / \mathrm{kg}$ (Rabelo $\mathrm{M}$ and Criddle DN, unpublished observations), greatly in excess of that required to produce an antinociceptive action, the current results indicate the potential of this plant essential oil as a therapeutic agent. Further detailed experiments are thus strongly indicated to clarify the properties of this medicinal plant and to investigate the mechanism of action of its essential oil.

\section{Acknowledgments}

We wish to thank Dr. J.H. Leal-Cardoso of the Departamento de Ciências Fisiológicas, Universidade Estadual do Ceará, for help and encouragement during the elaboration of this study.

\section{References}

1. Madeira SVF, Matos FJA, Leal-Cardoso JH \& Criddle DN (2002). Relaxant effects of the essential oil of Ocimum gratissimum on isolated ileum of the guinea-pig. Journal of Ethnopharmacology, 81: $1-4$.

2. Matos FJA (1998). Farmácias vivas: sistema de utilizacão de plantas medicinais projetado para pequenas comunidades. EUFC, Fortaleza, CE, Brazil, 220.

3. Oliver B (1960). Medicinal Plants in Nigeria. Nigerian College of Arts. Science and Technology, Ibadan, Nigeria, 42.

4. Aziba PI, Bass D \& Elegbe Y (1999). Pharmacological investigation of Ocimum gratissimum in rodents. Phytotherapy Research, 13: 427429.

5. Calixto JB, Beirith A, Ferreira J, Santos ARS, Cechinel Filho V \& Yunes RA (2000). Naturally ocurring antinociceptive substances from plants. Phytotherapy Research, 14: 401-418.

6. Koster R, Anderson M \& Debeer EJ (1959). Acetic-acid for analgesic screening. Federation Proceedings, 18: 412.

7. Huskaar S, Fasmer OB \& Hole K (1985). Formalin test in mice, a useful technique for evaluating mild analgesics. Journal of Neuroscience Methods, 14: 69-76.

8. Rosland JH, Tjolsen A, Maehle B \& Hole K (1990). The formalin test in mice: effect of formalin concentration. Pain, 42: 235-242.

9. Siegmund E, Cadmus R \& Lu G (1957). A method for evaluating both non-narcotic and narcotic analgesics. Proceedings of the Society for Experimental Biology and Medicine, 95: 729-731.

10. Berkenkopf JW \& Weichman BM (1988). Production of prostacyclin in mice following intraperitoneal injection of acetic-acid, phenylbenzoquinone and zymosan: its role in the writhing response. Prostaglandins, 36: 693-709.

11. Le Bars D, Gazariu M \& Cadden SW (2001). Animal models of nociception. Pharmacological Reviews, 53: 597-652.
12. Dickenson AH \& Sullivan AF (1987). Subcutaneous formalin induced activity of dorsal horn neurones in the rat: differential response to an intrathecal opiate administrated pre or post-formalin. Pain, 30: 349360.

13. Malmberg AB \& Yaksh TL (1995). Antinociceptive actions of spinal nonsteroidal antiinflammatory agents on the formalin test in the rat. Journal of Pharmacology and Experimental Therapeutics, 263: 136146

14. Shibata T, Ohkubo T, Tsuruda K \& Takahashi H (1994). Mode of analgesic action of phenolic dental medicaments through substance $\mathrm{P}$ release. Japanese Journal of Oral Biology, 36: 49-59.

15. Du Plooy WJ, Swart L \& Huysteen GW (2001). Poisoning with Boophane disticha: a forensic case. Human and Experimental Toxicology, 20: 277-278.

16. Brodin $P$ (1985). Differential inhibition of $A, B$ and $C$ fibers in the rat vagus nerve by lidocaine, eugenol and formaldehyde. Archives of Oral Biology, 30: 477-480.

17. Hirafuji M (1984). Inhibition of prostaglandin $I_{2}$ biosynthesis in rat dental pulp by phenolic dental medicaments. Japanese Journal of Pharmacology, 36: 544-546.

18. Dohi T, Anamura S, Shirakawa M, Okamoto H \& Tsujimoto A (1991). Inhibition of lipoxygenase by phenolic compounds. Japanese Journal of Pharmacology, 55: 547-550.

19. Patacchini R, Maggi CA \& Meli A (1990). Capsaicin-like activity of some natural pungent substances on peripheral endings of visceral primary afferents. Naunyn-Schmiedeberg's Archives of Pharmacology, 342: 72-77

20. Santos FA \& Rao VS (2000). Antiinflammatory and antinociceptive effects of 1,8-cineole a terpenoid oxide present in many plant essential oils. Phytotherapy Research, 14: 240-244. 